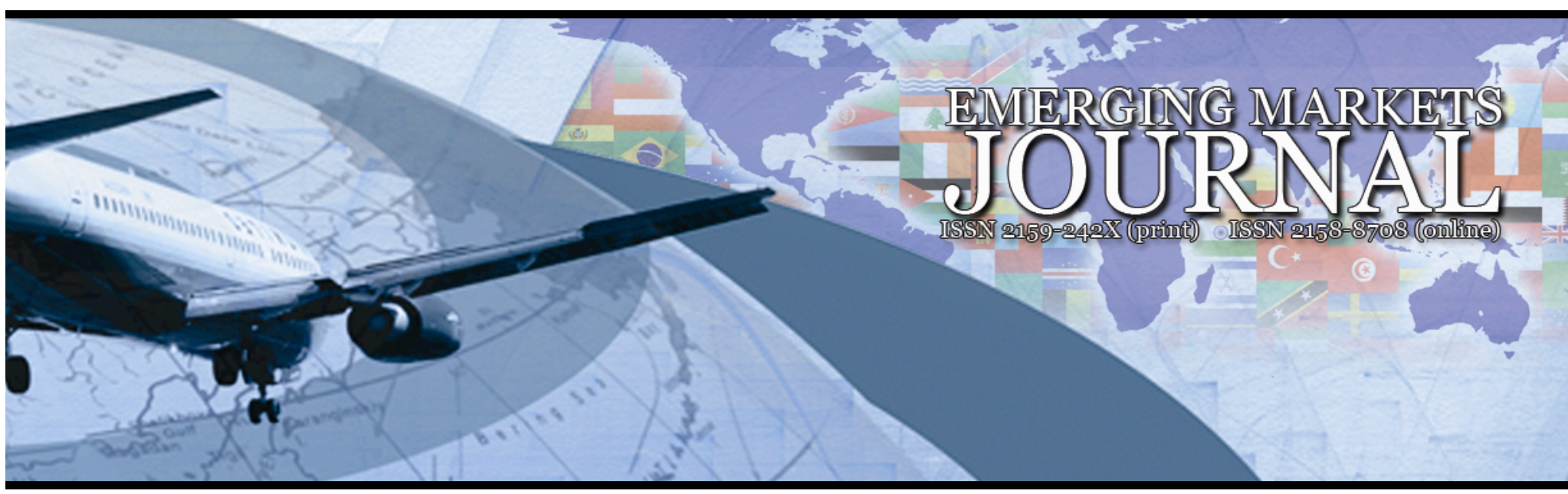

\title{
CORPORATE GOVERNANCE AND FIRM VALUE IN
} EMERGING MARKETS AN EMPIRICAL ANALYSIS OF ADR ISSUING EMERGING MARKET FIRMS

\author{
Aysun Ficici \\ Southern New Hampshire University | e-mail: a.ficici@snhu.edu \\ C. Bulent Aybar \\ Southern New Hampshire University
}

Volume 2(2012) | ISSN 2158-8708 (online) | DOI 10.5195/emaj.2012.18 | http://emaj.pitt.edu

Abstract

This study explores the value implications of good corporate governance for a sample of 54 ADR issuing emerging market firms (EMFs) from 9 countries primarily located in the regions of Asia, Eastern Europe and Latin America and the and employs recently constructed company composite corporate governance metric along with some alternative corporate governance measures associated with the origin of the issuing firm. Although the ADR literature primarily focuses on the impact of subscription to US disclosure requirements we contend that company and country specific corporate governance standards play a significant role in the risk reduction and ensuing value capture. The fundamental inquiry in this study has the following foci: The primary focus is on the impact of corporate governance structures on firm performance as to whether adherence to standards creates market value for ADR issuing EMFs. Do good corporate governance practices affect the value of EMFs? The secondary focus is concerned with whether the impact of corruption level and legal system in a firm's home country affect the corporate structures of EMFs thus affecting the market value of firms. In this study, we utilize Tobin's q as the measure of firm performance/market value. Our findings suggest that there is a significant correlation between corporate governance structures of ADR issuing EMFs and their market values and/or performances. The results also indicate that the level of corruption and legal structures in home countries of EMFs strongly impact the corporate governance structures of these firms and sequentially affect their market values. Therefore, this research further contributes to the scholarly findings and suppositions that corporate structures of firms do create consequences on firm value.

Keywords: Corporate Governance, Emerging Market, ADRs, Tobins Q, Firm Value

\section{(cc) BY-NC-ND}

This work is licensed under a Creative Commons Attribution-Noncommercial-No Derivative

Works 3.0 United States License.

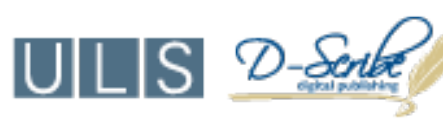

This journal is published by the University Library System of the University of Pittsburgh as part of its D-Scribe Digital Publishing Program, and is cosponsored by the University of Pittsburgh Press 
Corporate Governance and Firm Value in Emerging Markets An Empirical Analysis of ADR Issuing Emerging Market Firms

\author{
Aysun Ficici \\ C. Bulent Aybar
}

\section{Introduction}

Asymmetric information in financial markets is a taxing problem. An impediment to capital allocation is implicit in situations, which a capital user knows far more about his/her prospects and problems than the supplier of the capital. The resolution of information problems requires carefully designed control mechanisms such as appropriate contracts, courts to enforce these contracts, corporate governance rules, and financial intermediaries willing to act as corporate monitors. These mechanisms may either reduce the amount of information needed by the investors and intermediaries or may reduce the cost of collecting it. The acuteness of the information problems in emerging financial markets has been an escalating concern for global investors as the share of emerging market equities and bonds in global portfolio allocations grew substantially over the last decade. There is no sign of reversal in this trend as private capital flows in these countries gain further momentum in light of promising demographics and high growth prospects in emerging markets.

The literature on information problems in financial markets suggests that prevalence of information problems create a more conducive environment for the development of debt markets rather than public equity markets. In essence, equity investments are far more information intensive than debt, simply because equity investors own the residual claims on the company. Accordingly, they should be fully aware of the range of risks and opportunities facing the firm. This difficult task requires a complex screening assignment which is unlikely to be fulfilled by the average investor. Therefore, the access to equity markets require significant support from a range of institutions (eg underwriters, institutional investors and brokers), which should collectively provide objective information about the company prospects. It is no accident that the abundance of financial information and its effective dissemination is an invariable characteristic of developed equity markets where external equity constitutes a significant source of capital for corporations.

In the absence of such infrastructure, debt emerges as a practical and viable alternative to equity. Indeed debt contracts exist primarily to overcome information problems such as the ones encountered in equity markets. Unlike equity, debt creates simple, fixed obligations whose promised cash flows are the same regardless of how well or badly firm performs. The claims are in principle enforceable and almost everywhere debt holders are in a stronger position than holders of public equity to obtain their return in an environment of imperfect information.

The extent of informational asymmetry also determines the structure of debt markets. Relatively sophisticated debt securities such as bonds, notes and commercial papers are less likely to develop in environments characterized by inadequate informational infrastructure. Despite well defined cash flow rights, buyers of debt securities still need to feel that either they are themselves well informed or that some institution such as a rating agency is able to inform them indirectly about the company prospects. Banks in contrast generate their own private information and are thus the dominant suppliers of debt finance when public information is inadequate. Consequently, banks play a far larger role in 
markets where publicly available information is limited.

Informational asymmetries constitute an impediment in development of financial markets. Emerging markets suffer from this consequence. Information problems in emerging markets led to development of bank centered financial systems and left corporations with limited choice and variety of financial resources. Despite renewed attempts to jumpstart equity market development in emerging markets, relatively slow evolution of the institutional infrastructure limits widespread use of equity markets to finance growth. A natural outcome of this is over reliance on the internal funds and high cost of capital due to limitations of domestic financial markets. Because of rampant information problems, and infrastructure issues, equity is still very costly. Therefore, a growing number of EM companies attempt to overcome the limitations of domestic financial markets by subscribing to more stringent disclosure requirements in more developed financial markets particularly by accessing tools such as American Depositary Receipts (ADRs). ADR issuance is considered to be a strong signal to the market that the issuing company is ready for disclosure and compliance.

The commitment to increased levels of disclosure is expected to reduce the potential informational asymmetries between the management of the firm and its shareholders or among buyers and sellers of the firm's shares. The voluntary disclosure reduces the risk borne by the investors and increases liquidity of firm's stock by attracting larger group investors, who are more confident that the stock transactions occur at fair prices. Voluntary disclosure can also lower the cost of information acquisition for analysts and hence increase the supply of information about the company, reinforcing further reductions in informational asymmetry. As a result, EM firms committed to disclosure reduce their external cost of capital, and capitalize on the growth prospects in their respective markets.

Such a move by an EM firm theoretically has some value implications. In other words, in general commitment to good corporate governance should create value for the existing shareholders of the firm. The announcement and more importantly verification of such behavior should result in a decline in risk premium and therefore an increase in value. A number of empirical studies verify this expected increase in firm value in the context of event studies by analyzing the returns around the ADR listing (Miller 1999, Forrester and Karolyi 2000).

The subscription to higher standards of disclosure by issuing ADR in the US market is expected to generate the effects discussed above. Klapper and Love (2002) suggest that foreign firms issuing ADRs in the US on average have better operating performance and they attribute this finding to better corporate governance structures emerging as a result compliance to more stringent US disclosure requirements. We argue that a number of factors are expected to actively shape the resultant impact on performance and the value! First, there are different tiers of ADR markets with varying levels of disclosure and to best our knowledge there are no studies investigating the value implications for the issuing firms in the post listing period in relation to their commitment to better corporate governance. Secondly, the empirical literature analyzing value implications around the ADR issues report that risk reduction is more prevalent for developed country firms with poor corporate governance standards. Drawing on this literature, we argue that the impact of home country legal and regulatory environment should be considered. Finally, the extent of corruption in the home country setting would affect the commitment to better disclosure over the long run.

This study focuses on the impact of corporate governance structures on firm 
performance as to whether adherence to those standards creates market value and enhances performance for EMFs. We also explore whether the impact of corruption level and legal systems in a firm's home country affect the corporate governance structures of EMFs and subsequently affecting the market value and performance. We use a sample of ADR issuing emerging market firms, and employ recently constructed company composite corporate governance metric along with some alternative corporate governance measures associated with the origin of the issuing firm. Our sample is composed of a cross-section of $54 \mathrm{EM}$ firms in various industries from 9 countries (Brazil, Chile, India, Korea, Malaysia, Peru, Philippines, Taiwan and Thailand) primarily located in Asia and Latin America. Although the ADR literature primarily focuses on the impact of subscription to US disclosure requirements, such as increased exposure to the US capital market, and increased liquidity in equity through higher trading volumes, we contend that company and country specific corporate governance standards play a significant role in the risk reduction and ensuing value capture.

The study is organized as follows: Section two of the paper presents a review of the relevant literature. Section three focuses on Standard and Poor's (S\&P) governance benchmarks. Section four discusses the data and methodology. Section five presents empirical findings and finally section six concludes the paper with closing remarks.

\section{Corporate Governance, Performance and Value Linkage}

There is a growing body of literature in finance providing evidence on the linkage between corporate governance practices, corruption, legal infrastructure and firm performance and value. Doidge et.al (2001) show that home country characteristics defining governance structures such as inadequate investor rights and protection of minority interests are associated with poor performance and lower value. In a parallel study Dowell, Hart and Yeung (2000) suggest that companies with no or little stringent adaptation to global governance standards have lesser market value. In a study focusing on emerging market firms Klapper and Love (2002) argue that inefficient corporate governance structures and poor legal infrastructure increase risks associated with emerging market investments. In a single country study, Black, Jang and Kim (2003) examine the effects of corporate governance structures on the market value of Korean firms and suggest that corporate governance is a significant dynamic in explaining the market value of Korean public companies. Similarly, Black (2001) finds a robust relationship between the market value and corporate governance of a small sample of Russian firms.

A related body of research, which mainly includes firms from the United States and Western Europe focuses on ownership structure and shareholders rights and their impact on the firm value. La Porta et.al (1999) and La Porta et.al (2000) emphasize the value implications of potential conflicts of interest between the controlling and minority shareholders and insiders and outsiders when there is little or no transparency. When the interests of those who control the firm differ from the interests of those who supply the firm with external finances, the predicament evolves into principal agent problem and the ensuing agency costs have significant negative impact on firm value. Particularly interesting implications of the agency costs engendered by lack of transparency are the dividend policy and company's ability to exploit growth opportunities. The authors demonstrate that firms operating in countries, where minority shareholders are better protected, pay higher dividends. Those firms that experience faster growth pay lower dividends than the slower growing firms. This illustrates that when 
the shareholders are legally protected they are likely to wait since the investment opportunities are good. Conversely, poorly protected shareholders prefer not to wait no matter what the investment conditions are. This imperative leads to massive misallocation of funds, and in turn affects the firm value. Such conflicts of interest emanating from lack of transparency and inadequate regulatory safeguards to protect minority shareholders are endemic in emerging markets with non-negligible value implications.

Other research examines corporate governance and firm value by focusing on the issue of transparency from investors' perspective. Perotti and Von Thadden (1998) suggest that although corporate transparency has both strategic advantages and disadvantages, in general it has positive value implications since investors are able to receive meaningful information concerning their investments.

Recent proliferation of literature on economic implications of corruption suggests that private firms are entangled in the process as they take advantage of administrative corruption, involve in public procurement kickbacks and state capture . Xun (2002), examines the relationship between corporate governance and corruption. His findings suggest that poor corporate governance standards contribute to the proliferation of corruption by reducing transparency and impair the interests of investors. In countries with poor corporate governance practices, corruption develops into a transparency issue. Corruption may falsify the information received by the investors and the insiders may be treated preferentially through asset diversion, transfer prices and theft. Consequently, impaired investor trust exacerbated by poor corporate governance standards and corruption raise the cost of capital, negatively affect the operating performance and reduce value.

Finally, a growing body of literature indicates that variations in home country legal structure and the laws that protect investor across nations have significant impact on corporate governance mechanisms as well as ownership structure, dividend payout, cost of external finance and market valuations ((La Porta, Lopez-de-Silanes, and Vishny (1999); Klapper and Love, (2002)). While in some countries investor protection laws may not be binding since some firms may decline specific provisions, others, such as ADR issuing firms may implement additional provisions to improve investor protection rights by increasing disclosure, instituting better functioning boards and impose disciplinary means to ensure the rights of minority shareholders. Klapper and Love (2002) find that corporate governance structures are positively related to country level measures of investor protection and suggest that it is crucial for firms from countries with weak legal systems to adopt better corporate governance practices. Similarly, Black (2001) suggests that corporate governance structures of firms in developing countries can have larger effects, since these countries may have weaker rules.

\section{Data and Methodology}

\section{Data}

Our sample includes 54 companies from 9 emerging market countries with ADR issues in US. Our sample firms originate mostly from Asia and Latin America. Accounting data to measure firm performance was compiled from DataStream International. The governance data which includes S\&P's Corporate Governance Index and Composite Company Governance Scores (CGS) were obtained from Standard and Poor's. CGS is rated from 1 to 10 - 10 being highest adherence to corporate governance standards by firms. Corruption scores were obtained form Transparency International. The data for legal structures of firms is obtained from the Institute of Corporate Governance at Yale University. 


\section{Methodology}

\section{a. Performance Measures:}

We use several performance proxies based on accounting data. These performance proxies are Return on Assets (ROA) and Return on Equity (ROE). All return indicators are based on the earnings before interest taxes and depreciation (EBITD) due to its neutrality to depreciation methods, leverage and tax treatment. While all three indicators measure management's operating efficiency, they represent returns on different sources of capital.

We also use Tobin's $\mathrm{Q}$ which is an important and widely accepted measure of corporate performance. Tobin's-Q is defined as the ratio of market value of the firm to the replacement cost of its assets. We employed Doidge, Karolyi and Stulz's (2001) approximation to calculate the Q ratio:

$$
\text { Tobin's }-Q_{t}=\frac{\left(T A_{t}-B V E\right)+M V E}{T A_{t}}
$$

Where TA is the book value of the total assets of the firm, BVE is the book value of the firm's equity and MVE is the product of a firm's share price and the number of outstanding common shares. This indicator is employed to explain a number of diverse corporate phenomena such as cross-sectional differences in investment and diversification decisions, the relationship between managerial equity ownership and firm value. We are particularly interested in using Tobin's-Q to gain comparative insights on the effectiveness variant corporate governance practices adopted by emerging market firms on the firm value.

\section{b. Control Variables:}

We use size and leverage as control variables since their significance is empirically well established in literature addressing performance and value issues. While logarithm of sales and total assets are used as alternate size proxies, debt ratio is used as a measure of leverage.

\section{Corporate Governance Measures}

Our main corporate governance measure is Standard and Poor's Corporate Governance Scores (CGI). This index offers a detailed measure of a company's corporate governance standards by reference to global practices. Standard \& Poor's corporate governance profiles assign scores to companies according to their global practices. The assigned scores range from 1 to 10 , and 10 corresponds to best corporate governance practices. S\&P Total Decile Scores are employed as the general corporate governance index S\&P corporate governance index is composed of three subindices which collectively determine the overall CGI score. These three subcategory indices address various aspects of corporate governance. Sub-index-1 focuses on ownership structure and investor relations; sub-index-2 addresses financial transparency and information disclosure; and finally sub-index-3 measures the board, management and governance processes.

More specifically, ownership structure and investor relations sub-index is concerned with the role of stakeholders in corporate governance and equitable treatment of shareholders and it includes: (1) Fairness to minority shareholders in protecting against fraud, self-dealing or other insider wrongdoing; (2) Responsibility of the corporation as a member of society to abide by the laws and act with regard to society's needs. Corporate laws and regulations are also included in this subcategory. Financial transparency and information disclosure sub-index focuses on transparency and improved disclosure of accurate and timely information. Finally, board and management and processes sub-index is concerned with the rights of the shareholders 
and accountability of management through effective oversight based on a balance of power between the board of directors, managers, shareholders and the auditor.

\section{Legal System Proxies}

In an attempt to explore the linkage between the Corporate Governance structure of a firm and the legal structure of its home country, we developed a legal system proxy. We loaded 28 variables used by Lopez de Silanes to describe a country's legal structure into four principal components, namely Legal Structure, Shareholder Protection, Efficiency and Country Risk .

\section{Corruption Index}

The corporate governance scores of individual countries are obtained from Transparency International. The ratings are 10 to 1 . The score 1 indicates the highest level of corruption.

\section{a. Empirical Models:}

We use several alternative specifications to explore the impact of corporate governance, corruption and legal systems on the firm performance and value.

Our first specification uses Tobin's-q as a value metric. In addition to the Corporate Governance Index (CGI) composite score, we use variables to control for the size and the leverage.

$$
\begin{gathered}
\mathrm{TQ}={ }_{0}+{ }_{1} \mathrm{CGI}+{ }_{2} \mathrm{LEV}+{ }_{3} \\
\ln (\mathrm{SALES})+\quad(1)
\end{gathered}
$$

We also check the significance of the $\mathrm{CG}$ sub-indices by using the following specification:

$$
\mathrm{TQ}=\beta 0+\beta 1 \mathrm{Sub} 1+\beta 2 \mathrm{Sub} 2+\beta 3 \mathrm{Sub} 3
$$

$+\beta 4(\mathrm{LEV})+\beta 5 \ln (\mathrm{SALES})+\varepsilon$ (2)

Pricing inefficiencies and high volatility in emerging markets raise some questions about Tobin's-Q as a reliable value metric or performance measure. Therefore, we use ROA and ROE as alternative performance measures. Our specifications take the following form:

$$
\begin{aligned}
& \mathrm{ROA}=\beta 0+\beta 1 \text { CGI }+\beta 2 \mathrm{LEV}+\beta 3 \\
& \ln (\mathrm{SALES})+\varepsilon(3) \\
& \mathrm{ROA}=\beta 0+\beta 1 \mathrm{Sub} 1+\beta 2 \mathrm{Sub} 2+\beta 3 \\
& \mathrm{Sub} 3+\beta 4(\mathrm{LEV})+\beta 5 \ln (\mathrm{SALES})+\varepsilon(4) \\
& \mathrm{ROE}=\beta 0+\beta 1 \mathrm{CGI}+\beta 2 \mathrm{LEV}+\beta 3 \\
& \ln (\mathrm{SALES})+\varepsilon(5) \\
& \mathrm{ROE}=\beta 0+\beta 1 \mathrm{Sub} 1+\beta 2 \mathrm{Sub} 2+\beta 3 \\
& \mathrm{Sub} 3+\beta 4(\mathrm{LEV})+\beta 5 \ln (\mathrm{SALES})+\varepsilon(6)
\end{aligned}
$$

In order to explore regional and industry patterns we use region and industry dummies.

LA_DUMMY $=0$ if the firm belongs to an Asian country and 1 if it belongs to a Latin American country.

We classified firms into three types of industries based on their two digit SIC codes: i) Diversified ii) Service Industry and iii) Hightech Industry

DUMMY_SI $=1$ if industry is Service Industry 0 if the industry is High-tech industry

Diversified

DUMMY_DI $=1$ if industry represents

0 if the industry is High - Tech Industry

With the inclusion of regional and industry dummies, we use the following specifications:

$$
\begin{aligned}
& \mathrm{TQ}=\beta 0+\beta 1 \mathrm{CGI}+\beta 2 \mathrm{LEV}+\beta 3 \\
& \ln (\text { SALES }) \quad+\quad \beta 4 L A \_D U M M Y+\quad \beta 3 \\
& \text { DUMMY_SI+ } \beta 5 \text { DUMMY_DI }+\varepsilon \quad(7) \\
& \mathrm{TQ}=\beta 0+\beta 1 \mathrm{Sub} 1+\beta 2 \mathrm{Sub} 2+\beta 3 \mathrm{Sub} 3 \\
& +\quad \beta 4(\mathrm{LEV} \quad)+\beta 5 \quad \ln (\text { SALES })+ \\
& \beta 6 \mathrm{LA} \text { _DUMMY } \beta 7 \text { DUMMY_SI+ } \beta 8 \\
& \text { DUMMY_DI }+\varepsilon(8)
\end{aligned}
$$




$$
\begin{aligned}
& \mathrm{ROA}=\beta 0+\beta 1 \text { CGI }+\beta 2 \mathrm{LEV}+\beta 3 \\
& \ln (\text { SALES })+\beta 4 \text { LA_DUMMY }+\beta 3 \\
& \text { DUMMY_SI+ } \beta 5 \text { DUMMY_DI }+\varepsilon \text { (9) } \\
& \mathrm{ROA}=\beta 0+\beta 1 \text { Sub1 }+\beta 2 \text { Sub2 }+\beta 3 \\
& \text { Sub3 }+\beta 4 \quad(\text { LEV })+\beta 5 \quad \ln (\text { SALES })+ \\
& \beta 6 \text { LA_DUMMY }+\beta 7 \quad \text { DUMMY_SI }+\beta 8 \\
& \text { DUMMY_DI }+\varepsilon(10)
\end{aligned}
$$

We also explored the impact of legal system and the corruption on the firm performance by using the following specification.

$$
\mathrm{TQ}=\beta 0+\beta 1 \mathrm{LEV}+\beta 2 \ln (\mathrm{SALES})+\beta 3
$$

CGI $+\beta 4 \mathrm{CI}+\beta 5$ Legal Structure + $\beta 6$ Efficiency $+\beta 7$ Country Risk $+\beta 8$ Share holders protection (11)

$$
\mathrm{ROA}=\beta 0+\beta 1 \mathrm{LEV}+\beta 2 \ln (\mathrm{SALES})+
$$

$\beta 3$ CGI $+\beta 4$ CI $+\beta 5$ Legal Structure + $\beta 6$ Efficiency $+\beta 7$ Country Risk $+\beta 8$ Share holders protection (12)

\section{Value Creation}

We utilize the OLS method to address the research hypotheses:

Hypothesis 1: Corporate governance structure of a emerging market MNE affects its market value (MV).

Hypothesis 2: The level of Corruption in a country affects the market value of an emerging market MNE.

Hypothesis 3: Legal system/ structure in a country affects the corporate governance structure of an emerging market MNE, thereby affecting the market value of the firm..

\section{Empirical Findings}

\section{Data Analysis and Methodology}

OLS Results for Tobin's q and Corporate Governance, Corruption and Legal Structures: a. In order to find whether Corporate Governance structure of a firm affects its market value, a linear regression model is chosen:

$$
\mathrm{TQ}=\beta 0+\beta 1 \mathrm{CGI}+\varepsilon
$$

where TQ stands for Tobin's q, which is utilized as a proxy for market value. And CGI stands for Corporate Governance Index. The results as follows:

\begin{tabular}{|l|l|c|c|c|c|}
\hline VARIABLES & & T & $\mathbf{R}^{2}$ & ADJ R $^{2}$ & F \\
\hline Tobin Q Vs CGI \\
\hline CGI & $3.52 \mathrm{E}-01$ & $2.53 \mathrm{E}+00$ & 0.124 & 0.124 & 6.378 \\
\hline
\end{tabular}

The F-value is high and the t-statistic is greater than 2. Therefore, the above regression demonstrates that as Governance score increases, the market value increases by $35.2 \%$. Since a high number for CGI ranking indicates good governance, we find that as firms implement strong governance

\begin{tabular}{|c|c|c|c|c|c|}
\hline VARIABLES & & $\mathrm{T}$ & $\mathbf{R}^{2}$ & $\begin{array}{c}\text { ADJ } \\
\mathbf{R}^{2}\end{array}$ & $\mathbf{F}$ \\
\hline \multicolumn{6}{|c|}{ Tobin Q Vs CGI,EBIT/SALES } \\
\hline CGI & $\begin{array}{c}4.54 \mathrm{E}- \\
01\end{array}$ & $2.83 \mathrm{E}+00$ & 0.165 & 0.124 & 4.043 \\
\hline EBIT/SALES & -0.172 & -1.072 & & & \\
\hline
\end{tabular}
practices, their market values increase. Therefore, the results support Hypothesis 1.

b. It may be possible that the firm's profitability may affect the market value. Therefore, to control for the profitability effect we add the EBIT/SALES variable into the model.

$$
\mathrm{TQ}=\beta 0+\beta 1 \mathrm{CGI}+\beta 2 \mathrm{EBIT} / \mathrm{SALES}+\varepsilon
$$

The following table shows the results of the regression:

The adjusted R-square remains the same indicating that the added variable does not 
contribute much in explaining the variation in the data. Firm's profitability (measured by EBIT/SALES) is negatively correlated with TQ. The T-statistic of $\beta 1$ increases, which strengthens the variable in the model. The above regression displays that as Governance score of a firm increases, its market value increases by $45.4 \%$. Hence the results from this regression as well support Hypothesis 1.

c. The size of a firm may also affect the market value. To control for this effect, we add the $\ln$ (assets) into the model. We use $\ln$ (assets) as a proxy for firm size.

$\mathrm{TQ}=\beta 0+\beta 1 \mathrm{CGI}+\beta 2 \mathrm{EBIT} / \mathrm{SALES}+\beta 3$ $\ln (\operatorname{ASSETS})+\varepsilon$

\begin{tabular}{|c|c|c|c|c|c|}
\hline VARIABLES & & $\mathrm{T}$ & $\mathbf{R}^{2}$ & $A D J^{2}$ & F \\
\hline \multicolumn{6}{|c|}{ TOBIN Q Vs CGI,EBIT/SALES,LN(SALES) } \\
\hline CGI & .466 & $.63 \mathrm{E}+00$ & .165 & .103 & .64 \\
\hline \multirow{2}{*}{$\begin{array}{l}\text { EBIT / } \\
\text { ALES }\end{array}$} & & & & & \\
\hline & 0.17 & $1.04 \mathrm{E}+00$ & & & \\
\hline \multirow{2}{*}{$\begin{array}{l}\text { LN(SA } \\
\text { LES) }\end{array}$} & & & & & \\
\hline & .027 & $.62 \mathrm{E}-01$ & & & \\
\hline
\end{tabular}

The adjusted R-square has decreased indicating that \begin{tabular}{|c|c|c|c|c|c|}
\hline VARIABLES & $\mathbf{T}$ & $\mathbf{R}^{2}$ & $\mathbf{R}^{2}$ & $\begin{array}{l}\text { ADJ } \\
\text { the added variable does not contribute in explaining } \\
\text { the variation in the data. Hence we take Ln(assets) } \\
\text { as a better proxy for firm size. }\end{array}$
\end{tabular} TOBIN Q Vs CGI,EBIT/SALES,LN(ASSETS)

\begin{tabular}{|c|c|c|c|c|}
\hline CGI & 0.536 & $3.19 \mathrm{E}+00$ & 0.206 & 0.147 \\
\hline EBIT / SALES & 0.218 & $\begin{array}{c}- \\
1.35 \mathrm{E}+00\end{array}$ & & \\
\hline LN(ASSETS) & 0.217 & $1.45 \mathrm{E}+00$ & & \\
\hline
\end{tabular}

The adjusted R-square has increased indicating that the added variable contributes in explaining the variation in the data. Size of the firm (measured by $\ln ($ ASSETS $)$ ) is positively correlated with TQ. The above regression shows that as Governance score increases, the market value increases by $53.6 \%$; thereby, it supports Hypothesis 1.

d. Ln(sales) could also be a measure of firm's size. Hence we regress with $\ln$ (sales) instead of $\ln$ (assets).

$$
\begin{aligned}
& \mathrm{TQ}=\beta 0+\beta 1 \mathrm{CGI}+\beta 2 \text { EBIT/SALES }+\beta 3 \\
& \ln (\mathrm{SALES})+\varepsilon
\end{aligned}
$$

The investor's confidence of a firm might result in a greater market value. To control for this effect $\mathrm{BV} / \mathrm{MV}$ is added to the model.

$\mathrm{TQ}=\beta 0+\beta 1 \mathrm{CGI}+\beta 2 \mathrm{EBIT} / \mathrm{SALES}+\beta 3$

$\ln (\mathrm{SALES})-\beta 4 \mathrm{BV} / \mathrm{MV}+\varepsilon$

\begin{tabular}{l|l|l|l|l|l} 
& & & & ADJ & \\
VARIABLES & & $T$ & $R^{2}$ & $R^{2}$ & $F$
\end{tabular}

\begin{tabular}{|c|c|c|c|c|c|}
\hline CGI & 03 & 3.975 & 0.525 & 0.477 & 10.785 \\
\hline EBIT/SALES & $\begin{array}{l}-1.81 \mathrm{E}- \\
02\end{array}$ & 2.038 & & & \\
\hline LN(ASSETS) & 03 & 3.000 & & & \\
\hline MV TO BV & & 5.117 & & & \\
\hline
\end{tabular}

TOBIN Q Vs CGI,EBIT/SALES,LN(ASSETS),MV TO BV

From the above regression we observe that the model improves. Adjusted R-square has increased. $\mathrm{MV} / \mathrm{BV}$ explains $1.81 \%$ of the variation in the data. 
f. Next Tobin's Q is regressed against the Corruption index to find whether corruption affects the market value of a firm.

\begin{tabular}{|c|c|c|c|c|c|c|}
\hline VARIABLES & T & $\mathbf{R}^{2}$ & ADJ R $^{2}$ & F \\
\hline \multicolumn{7}{|l|}{ TOBIN Q Vs CORRUPTION INDEX } \\
\hline
\end{tabular}

There seems to be a negative relation between corruption and TQ, indicating that as corruption scores go up (high corruption), the market value of the firm decreases. The findings state that high corruption level within a country decreases firm value. The results support hypothesis 2 .

g. To find the relationship between Market Value (Tobin's Q) and the 4 principal components: structure, efficiency, country risk and shareholders protection the following model is utilized:

$\mathrm{TQ}=\beta 0+\beta 1$ Legal Structure $+\beta 2$ Efficiency $+\beta 3$ Country Risk $+\beta 4$ Share holders protection $+\varepsilon$

\begin{tabular}{|l|l|l|l|l|l|l|}
\hline \multicolumn{2}{|c|}{ VARIABLES } & & $T$ & $R^{2}$ & ADJ R $^{2}$ & F $^{2}$ \\
\hline $\begin{array}{l}\text { TOBIN Q VS LEGAL STRUCTURE,EFFEICIENCY,COUNTRY RISK,SHARE } \\
\text { PROTECTION }\end{array}$ & HOLDERS \\
\hline & LEGAL STRUCTURE & -0.946 & $-3.48 \mathrm{E}+00$ & 0.388 & 0.33 & 6.656 \\
\hline & EFFICIENCY & 0.025 & 0.207 & & & \\
\hline & COUNTRY RISK & 1.38 & 4.564 & & & \\
\hline
\end{tabular}

Judging from the above regression, it can be noted that the type of legal structure explains $94.6 \%$ of the variation in the data. (Type of legal structure: depending whether the country adheres to Swiss Law, German Law or British Law). As the efficiency of the legal structure increases, the market value increases by $2.5 \%$. As country risk increases the market value increases $138 \%$ and as shareholders' protection increases, market value of the firm decreases by $67.6 \%$. The results from this regression support hypothesis 3, illustrating that legal structure in a country, country risk, and shareholder protection do affect firm value. Here some effects on market value are negative.

h. The effect of the three sub indices used in the computation of Corporate Governance scores on Tobin's Q is obtained from the following regression:

$$
\mathrm{TQ}=\beta 0+\beta 1 \mathrm{Sub} 1+\beta 2 \mathrm{Sub} 2+\beta 3 \mathrm{Sub} 3+\varepsilon
$$




\begin{tabular}{|c|c|c|c|c|c|}
\hline VARIABLES & & $\mathrm{T}$ & $\mathbf{R}^{2}$ & ADJ $R^{2}$ & F \\
\hline \multicolumn{6}{|l|}{ TOBIN Q VS SUB1,SUB 2,SUB 3} \\
\hline $\begin{array}{l}\text { SUB1 - Ownership Structure and Investor } \\
\text { Relations }\end{array}$ & 0.875 & 4.567 & 0.355 & 0.309 & 7.873 \\
\hline $\begin{array}{l}\text { SUB } 2 \text { - Financial Transparency and Information } \\
\text { Disclosure }\end{array}$ & -0.04 & -0.234 & & & \\
\hline SUB 3 - Board and Management and processes & -0.442 & -2.049 & & & \\
\hline
\end{tabular}

From the above regression it can be inferred that as Ownership structure and Investor relations scores increase, market value increases by $87.5 \%$. High Financial Transparency and Information disclosure scores cause a decrease in the Market Value by 4\%. An increase in Board and Management process scores causes the decrease in the market value by $44.2 \%$. The results support hypothesis 1 . However, Ownership structure and Investor relations have positive effect on firm market value, and sub category 2 - Financial Transparency and Information Disclosure, and sub category 3 - Board and Management process have negative effects on firm market value.

b. In order to find whether Corporate Governance structure of a firm across the geographical region affects its market value, the following linear regression model is employed:

$$
\mathrm{TQ}={ }_{0}+{ }_{1} \mathrm{CGI}+{ }_{2} \mathrm{LA} \_\mathrm{DUMMY}+
$$

LA_DUMMY $=0$ if the firm is in Asia and 1 if in Latin America. This model assumes that the rate of change of market value with respect to CGI is a constant across the two countries.

The results are the following:

\begin{tabular}{|c|c|c|c|c|c|}
\hline VARIABLES & & $\mathrm{T}$ & $\mathbf{R}^{2}$ & $\mathrm{ADJ} \mathrm{R}^{2}$ & $\mathbf{F}$ \\
\hline \multicolumn{6}{|c|}{ Tobin Q Vs CGI \& COUNTRY DUMMY } \\
\hline CONST & 0.978 & 298.043 & & & \\
\hline CGI & $2.259 \mathrm{E}-03$ & 2.819 & .318 & .287 & 10.242 \\
\hline LA_DUMMY & $1.352 \mathrm{E}-02$ & 3.533 & & & \\
\hline
\end{tabular}

The two equations obtained are as follows:

For firms in Latin America,

$\mathrm{TQ}=1.978+2.259 \mathrm{E}-03 \mathrm{CGI}+\varepsilon$ 
For firms in Asia

$\mathrm{TQ}=0.978+2.259 \mathrm{E}-03 \mathrm{CGI}+\varepsilon$

The above equations suggest that the mean of the Tobin's Q in Latin America is higher than those of Asia. This could be attributed to investor's perceptions or any such external variables outside the scope of this research.

j. In order to find whether Corporate Governance structure of a firm across the industry affects its market value, the following linear regression model is chosen:

$$
\mathrm{TQ}=\beta 0+\beta 1 \mathrm{CGI}+\beta 2 \mathrm{DUMMY} \mathrm{MI}+\beta 3 \mathrm{DUMMY} \mathrm{SI}+\varepsilon
$$

The above model assumes that the rate of change of market value with respect to CGI in the two geographical areas is a constant. Three types of industries are identified as i) Mixed Industry ii) Service Industry and iii) High-tech Industry

Where,

DUMMY_SI $=1$ if industry is Service Industry

0 if the industry is High-tech industry

DUMMY_MI $=1$ if industry represents Mixed Industry

0 if the industry is High - Tech Industry

\begin{tabular}{|c|c|c|c|c|c|c|}
\hline \multicolumn{2}{|c|}{ VARIABLES } & & T & R $^{2}$ & ADJ R & F \\
\hline \multicolumn{7}{|c|}{ Tobin Q Vs CGI \& INDUSTRY DUMMY } \\
\hline & CGI & $8.829 \mathrm{E}-04$ & 1.023 & .372 & .328 & 8.474 \\
\hline & DUMMY_MI & $1.376 \mathrm{E}-02$ & 4.049 & & & \\
\hline & DUMMY_SI & $5.217 \mathrm{E}-03$ & 1.809 & & & \\
\hline
\end{tabular}

Assuming that the rate of change of market value with respect to CGI in the two geographical areas is a constant, the following three equations can be obtained from the above regression for the three industries:

1. Service industry

$$
\begin{gathered}
\mathrm{TQ}=(0.978+5.217 \mathrm{E}-03)+8.829 \mathrm{E}-04 \mathrm{CGI}+\varepsilon \\
=0.983217+8.829 \mathrm{E}-04 \mathrm{CGI}+\varepsilon
\end{gathered}
$$

2. Mixed Industry

$$
\begin{aligned}
\mathrm{TQ} & =(0.978+1.376 \mathrm{E}-02)+8.829 \mathrm{E}-04 \mathrm{CGI}+\varepsilon \\
& =0.99176+8.829 \mathrm{E}-04 \mathrm{CGI}+\varepsilon
\end{aligned}
$$

3. High - Tech Industry 
$\mathrm{TQ}=(0.978)+8.829 \mathrm{E}-04 \mathrm{CGI}+\varepsilon$

The results indicate that the mean market value of firms in the Mixed Industry category is higher than the other two categories as given by the y-intercept. The mean market value of the firms in the Service industry is higher that the ones in the high-tech industry.

\section{Conclusion}

The results support a positive correlation between Tobin's q (market value of the firm) and total corporate governance scores of emerging market MNEs. Thereby supporting the hypothesis corporate governance structures of emerging market MNEs affect their firm value and value creation. When there is better corporate governance within the firms, the market value of firms increase.

When we consider the sub-indices separately in the regression model, it is inferred that as Ownership structure and Investor relations' scores increase, market value of a firm increases as well. However, High Financial Transparency and Information disclosure scores cause a decrease in the firm market value. Additionally, an increase in Board and Management process scores, causes a decrease in the market value of the firm.

The results also report that there is a negative relationship between Tobin's $\mathrm{q}$ and corruption, indicating that as corruption scores go up (high corruption level within a country), the market value of the firm decreases. The findings state that high corruption level within a given country decreases firm value.
The type of legal structure explains $94.6 \%$ of the variation in the data. (Type of legal structure: depending whether the country adheres to Swiss Law, German Law or British Law). As the efficiency of the legal structure increases, the market value increases by $2.5 \%$. As country risk increases the market value increases $138 \%$ and as shareholders' protection increases, market value of the firm decreases by $67.6 \%$.

This research further contributes to the studies relating corporate governance and market value, as it confirms a positive relationship between the two variables. The research also includes control variables that were not previously used in other studies. Therefore it can be said that it is more robust than the other studies. Our findings suggest that it is imperative for firms to enhance their corporate governance standards in order to increase firm value. The findings also suggest that investors need to be extra cautious when investing in firms with less stringent corporate governance mechanisms. Future studies in this area can be expanded by incorporating other variables to control for factors outside of the scope of this study.

\section{References}

1. Agrawal, Anup. and Knoeber, Charles R. "Firm Performance and Mechanisms to Control Agency Problems between Managers and Shareholders". Journal of Financial and Quantitative Analysis, 31(1996).

2. Black, Jang and Kim (2003), “Does Corporate Governance Affect Firms’ Market Values?,’Social Science Research Network electronic library at: http://papers.ssrn.com/abstract $=311275$.

3. Black, Bernard (2001), "The Corporate Governance Behavior and Market Value of Russian Firms," Emerging Markets Review, vol. 2, pp. 89-108. 
4. Doidge, C, Andrew Karolyi, and Rene M. Stulz (2002), "Why are Foreign Firms Listed in the U.S. Worth More?," working paper at: http://ssrn.com/abstract $=2853397$.

5. Dowell, Hart and Yeung (2000), Do Corporate Global Environmental Standards Create or Destroy Market Value? Management Science. Vol, 46 no. 8 1059-1074.

6. Fama, E., L. Fisher, M. Jensen and R Roll. (1969) “The Adjustment of Stock Prices to New Information.” International Economic Review 10: 1-21.

7. Gompers, P, Joy L.Ishii, and Andrew Metrick (2003), "Corporate Governance and Equity Prices", Quarterly Journal of Economics, vol. 118, pp. 107-155.

8. Hellman, J., G. Jones, and D. Kaufmann (2000), “Are Foreign Investors and Multinationals Engaging in Corrupt Practices in Transition Economies?” The World Bank/The William Davidson Institute.

9. Hellman, Joel and Jones, Geraint and Kauffman, Daniel and Schankerman, Mark A. "Measuring Governance, Corruption, and State Capture: How Firms and Bureaucrats Shape the Business Environment in Transition Economies". World Bank Institute of Governance, Regulation and Finance. 2312. Washington D.C. (2000).

10. Kaufmann, D., and S.-J. Wei (1999), "Does 'Grease Money' Speed Up the Wheels of Commerce?" The World Bank and Harvard University. Working paper. No. 2254.

11. Kaufmann, D., and S.-J. Wei (2000), "Measuring Governance, Corruption, and State Capture - how firms and bureaucrats shape the business environment in transition economies" The World Bank and Harvard University. Working paper No. 2312.

12. Klapper, L. and Inessa Love (2002), "Corporate Governance, Investor Ptotection, and Performance in Emerging Markets”, World Bank Policy Research Working Paper 2818.

13. LaPorta, R. F. Silanes, and A. Shleifer (1999) "Corporate Ownership Around the World," Journal of Finance, vol. 54, pp. 471-517.

14. LaPorta, R. F. Silanes, A. Shleifer, and R.W. Vishny (2000) "Agency Problems and Dividend Policies Around the World," Journal of Finance, vol. 55, pp. 1-33.

15. LaPorta, Rafael and Lopez de Silanes, Florencio and Shleifer, Andrei and Vishny, Robert W. (2000). "Investor Protection and Corporate Governance". Journal of Financial Economics. 58, pp. 3-27.

16. Maher, M. and T. Andersson (2000), Convergence and Diversity of Corporate Regimes and Capital Markets, Oxford University Press, Oxford.

17. Modigliani, Franco and Enrico Perotti (2000), "Security Versus Bank Finance: The Importance of a Proper Enforcement of Legal Rules," International Review of Finance, vol. 1, pp. 81-96.

18. OECD Report (1987 - 1997).

19. OECD, "Principles of Corporate Governance". Organisation for Economic Cooperation and Development. Accessed June 2, 2004. http:www.oecd.gov

20. Patel, S.A., Amra Balic, and Liliane Bwakira (2002), "Measuring Transparency and Disclosure at FirmLevel in Emerging Markets," Emerging Markets Review, vol.5, pp. 169-191. 
21. Transparency International. CPI Index. http://www.transparency.org/policy_research/surveys_indices/cpi .

22. Stulz, Rene M and Lang, Larry H P. (1994). Tobin's q, Corporate Diversification, Journal of Political Economy. 102:6, pp. 1248-80.

23. Woochan, Kim and Black, Bernard, S. and Jang, Hasung. .(2003) "Does Corporate Governance Affect Firms' Market Values?” Social Science Research Network.

24. Xun, Wu, (2002), "Corporate Governance and Corruption: A Cross Country Analysis," Public Policy Program, National University of Singapore. 